New England Journal of Entrepreneurship, Vol. 19 [2016], No. 1, Art. 1

\title{
An Examination of Job Opportunities, Candidates, and Salaries in the Field of Entrepreneurship
}

Todd A. Finkle

$T$ his article examines whether the field of entrepreneurship is becoming increasingly institutionalized by examining market trends, AACSB jobs, and salaries. The findings indicate that the field is becoming increasingly institutionalized through market trends. During 2014/15, there were 471 advertised positions and 163 candidates in Schools of Business and Management. The number of tenure track positions (261) was significantly higher than the number of tenure track candidates (161) for a ratio of 1.62. This is the highest ratio of tenure track positions to candidates since 2005/06 (2.1). Out of the 261 tenure track positions, 174 were at AACSB institutions. The ratio of tenure track positions at AACSB schools per tenure track candidate was 1.08. The study also looked at average salaries at AACSB schools and found them to be competitive with other mainstream areas. Average salaries were: full professors $(\$ 162,000)$, associate professor $(\$ 131,400)$, assistant professor $(\$ 113,600)$, instructor $(\$ 85,800)$, and new doctorates $(\$ 97,800)$.

Keywords: entrepreneurship; faculty; salaries; job opportunities; higher education; AACSB

Entrepreneurship education continues to be a popular area of study within Schools of Business in higher education. Despite this, virtually little research has been done on salaries within the field. If the field can understand the trends occurring with salaries and how they compare with other more established fields (e.g., finance, accounting, marketing, etc.), it can determine whether it is becoming institutionalized within Schools of Business in higher education. The purpose of this study is to determine if the field of entrepreneurship is becoming increasingly institutionalized by examining salaries. The study also examines the current market trends (jobs and candidates) and Association to Advance Collegiate Schools of Business (AACSB) jobs in the field of entrepreneurship.

Institutional theory (Meyer and Rowan, 1977; Loundsbury, 2002; Bruton, Ahlstrom, and Li, 2010) posits that organizations operating in institutionalized environments are acting in a legitimate manner by adopting the structures and activities perceived to be legitimate by their critical external resource providers (Finkle and Deeds, 2001). In essence, by adopting appropriate structures the organization increases its legitimacy and is able to use this legitimacy to increase its support and ensure its survival (Dowling and Pfeffer, 1975; Meyer and Rowan, 1977). In other words, are entrepreneurship faculty earning competitive salaries? The importance of understanding whether the field of entrepreneurship is becoming institutionalized is critical to the legitimacy, growth, and sustainability of the field.

The study answers the following research questions: (1) What are the market trends for entrepreneurship faculty? (2) What are the market trends for faculty in higher education for tenure track positions in entrepreneurship (including tenure track AACSB positions)? and (3) Are the average salaries of entrepreneurship faculty at AACSB schools competitive with other more established fields such as finance, accounting, management, and marketing?

The results of this study provide updated information in regards to jobs, candidates, and tenure track positions. But more importantly, it investigates the trends that are currently occurring to salaries within the field. Sparse research exists in this area. The findings of this study can make a significant impact on how the field compares to other disciplines. Furthermore, the findings will provide faculty, doctoral students, and administrators with information to be proactive with their strategies in the workplace.

\section{Previous Research}

Several studies have examined market trends and AACSB jobs in the field of entrepreneurship. Finkle and Deeds $(2001 ; 2002)$ pioneered the first study on the growth in the field of entrepreneurship in regards to job opportunities and candidates. Their findings concluded that the field was becoming increasingly institutionalized, but came up short in a number of areas (e.g., most of the positions were not tenure track, there was no mandate for entrepreneurship education, entrepreneurship was primarily an elective, and departments were rare). They concluded that the field had a long way to go to become institutionalized.

Other researchers investigated the growth of entrepreneurship centers (see Finkle, 2007a; 2007b; 2008; Finkle and Kuratko, 2004; 2006; Finkle, Kuratko and Goldsby, 2006a; 2006b; Finkle, Menzies, Kuratko 
and Goldsby, 2010; 2012; 2013). Based on their findings, the field of entrepreneurship has become increasingly institutionalized due to the growing number of entrepreneurship centers. Entrepreneurship centers measure an institution's commitment to entrepreneurship. They must dedicate resources to hire a director and almost all centers have a curriculum. These centers also bring legitimacy to a school's entrepreneurship program.

Another area that has been investigated is tenure. If entrepreneurship faculty is getting tenure, this would certainly be a measure that the field is increasingly becoming institutionalized. Finkle, Stetz and Deeds (2004) and Finkle, Stetz and Mallin (2007) looked at differences in tenure applications for entrepreneurship faculty at research versus teaching schools. They found that 87 percent of the successful tenure candidates of entrepreneurship faculty at research schools had at least one top A-level journal publication. The remaining 13 percent that earned tenure attributed their success to a number of other tangible skills they brought to their respective institutions (e.g., administrator of an entrepreneurship center, fundraising, continuing education, etc.). At teaching schools, they found that it was possible to earn tenure without publishing in top management journals or any other leading journals. Entrepreneurship was also valued higher at teaching schools.

They concluded that most of the candidates earned tenured, however research was the cause for the ones that did not earn tenure. Of the tenure candidates, 95 percent that did not earn tenure was due to research. Therefore, they recommended that at both research and teaching schools, candidates target at least one A-level publication (as ranked by their institution). Even if the respective teaching school does not require that level of publication, it allows faculty much more flexibility and ability to advance in their careers.

Finkle's (2010) study found that entrepreneurship was increasingly institutionalized on a global basis. The study saw international jobs grow from 0 in 1989 to 76 in 2007/08 with the growth of international positions more than doubling from 2006/07. Finkle's (2012a; 2012b) studies indicate a maturity in the rate of tenure track positions - 203. This may have been caused by the Great Recession as the number of tenure track positions peaked right before it at 292 and then decreased. Since 2007/08 when there were 288 tenure track positions, the numbers have decreased. Finkle (2013a, 2013b) looked at the characteristics of the job market from 1989-2013 and concluded that the field had a strong demand for candidates with a primary interest in entrepreneurship and senior faculty. There was a very high demand for senior faculty with 87 percent of the job opportunities targeted at this level. This was evidence on a different level that schools were increasingly institutionalizing entrepreneurship into their structures.

\section{AACSB}

This study builds on previous research by examining not only market trends but also changes in the number of AACSB job opportunities, and salaries in the field. An increase in the number of tenure track AACSB positions should signal that the field is becoming increasingly institutionalized.

AACSB schools have to pass a voluntary, nongovernmental review of educational institutions and programs. According to AACSB (2015), its accreditation depicts the highest measure of achievement for schools of business worldwide. Schools that earn AACSB accreditation are committed to quality and continuous improvement.

The only study in the field of entrepreneurship that has examined market trends and AACSB positions was Finkle (2007a). He examined the trends in jobs and candidates from 1989 to 2005 and found 122 tenure track AACSB positions and 102 tenure track candidates or 1.2 tenure track AACSB positions per tenure track candidate. Additionally, only 33 (32\%) of the tenure track candidates had a primary interest in entrepreneurship.

\section{Salaries}

The field of entrepreneurship has performed sparse research on the topic of salaries. Finkle (2016) examined entrepreneurship faculty salaries and faculty demand. Katz (2004) focused on compensation for endowed chairs. He looked at stipends, travel, salaries, research funding, and course loads and found that the average annual salary for an endowed chair was $\$ 162,018$ (Median $=\$ 148,500)$.

More recently, Finkle et al. (2010; 2012; 2013) examined entrepreneurship center directors' salaries. Their first study in 2012 found that the average annual salary of a U.S.

center director was $\$ 145,948$. In 2013 , they found that the average annual salary was $\$ 136,989$ versus $\$ 131,250$ for an international center director.

This study looks at entrepreneurship faculty salaries and how they compare to other mainstream fields of business. Specifically, it examines the average salary and rank for entrepreneurship faculty.

40 NEW ENGLAND JOURNAL OF ENTREPRENEURSHIP 


\section{Methodology}

The data for this study was collected over a 26-year period. In the late 1980s and early 1990s, data was collected from small booklets (Academy of Management Placement) sent out to Academy of Management members. These numbers were supplemented by searching hard copies and microfiche of all of the advertisements in the newspaper edition of the Chronicle of Higher Education. By the mid-1990s, the booklets turned into a larger newspaper format. Both candidates and jobs were listed along with a short advertisement.

In the 1990s, advertisements started appearing on the Internet. Initially, there was no central place for jobs; however, over time, the Academy of Management Placement was transformed as a major place to advertise for candidates and schools. Several other sites also listed job opportunities. Table 1 lists sites used to collect data for this study. Job data was also collected through e-mails on a variety of networks and directly from universities.

A database was created to collect and analyze information. Data were collected from July 1 through June 30 for each academic year.

The data for salaries were based on an annual survey of 325 American AACSB schools within the United States from 2004-2015. Salaries of faculty included nine-month contracts and did not include summer pay, stipends, or other benefits.

\section{Results and Discussion}

Five tables were created to answer the three research questions. The first three focused on market trends. Table 2 examines the number of candidates and positions from 1989 through 2015. It breaks down the data into interest level (e.g., primary, secondary, or tertiary). International candidates and jobs were also evaluated. Table 3 evaluates the number and percentage of tenure track positions and candidates. Tenure track positions were broken down by rank (e.g., assistant, associate, full, endowed, or open). Table 3 looks at the advertisements of the positions and candidates. For example, Cornell University is seeking a candidate with a primary area in entrepreneurship, but it also seeks a person with a secondary area in business policy and a tertiary area in technology and innovation management. Table 4 evaluates the percentage of candidates and candidates that have advertisements in different areas.

Table 5 examines the trends of salaries over the past nine years for entrepreneurship faculty at AACSB schools in the United States. Table 6 examines the average entrepreneurship faculty salaries by rank compared to other business disciplines with a primary focus on accounting, finance, management and marketing during 2014-2015.

Table 2 shows the total number of jobs (tenure track and non-tenure track) over the past 26 years. The total number of jobs was the highest ever this past academic year, 2014/15, at 471. During 1989 to 2015, the lowest number of job advertisements was 18 in 1991/92. By $2014 / 15$, the number of jobs had increased by 2,517 or an average of 97 percent a year.

\section{Table 1. List of Web Sites Used to Collect Data on Schools}

Academic 360 (http://www.academic360.com/general/UK.cfm)

Academic Careers Online (http://www.academiccareers.com/)

Academic Employment Network (http://www.academploy.com)

Academic Jobs EU (http://www.academicjobseu.com/)

Academic Keys for Business Education (http://business.academickeys.com/seeker_job.php)

HigherEdJobs.com (http://www.higheredjobs.com/)

Indeed.com (http://www.indeed.com/)

Jobs.ac.uk (http://www.jobs.ac.uk)

Mid Atlantic Higher Education Consortium (http://www.midatlanticherc.org/home/)

United States Association for Small Business and Entrepreneurship (USASBE) (http://usasbe.org/)

University 500 (http://www.university500.com/)

University Affairs (http://oraweb.aucc.ca/pls/ua/english_search) 
Table 2. Number and Level of Interest in Entrepreneurship for Candidates and Positions 1989-June 2015

\begin{tabular}{|c|c|c|c|c|c|c|c|c|c|c|}
\hline Academic Yr. & $\begin{array}{l}\text { Candidates } \\
\text { w/Primary } \\
\text { Interest }\end{array}$ & $\begin{array}{c}\text { Positions } \\
\text { w/Primary } \\
\text { Assignment }\end{array}$ & $\begin{array}{l}\text { Candidates } \\
\mathrm{w} / 2^{\text {nd }} \text { Interest }\end{array}$ & $\begin{array}{l}\text { Positions } \\
w / 2^{2 d} \\
\text { Assignment }\end{array}$ & $\begin{array}{c}\text { Candidates } \\
\text { w/Tertiary } \\
\text { Interest }\end{array}$ & $\begin{array}{c}\text { Positions } \\
\text { w/Tertiary } \\
\text { Assignment }\end{array}$ & $\begin{array}{c}\text { Int'I } \\
\text { Candidates }\end{array}$ & $\begin{array}{c}\text { Int'I } \\
\text { Positions }\end{array}$ & $\begin{array}{c}\text { Total } \\
\text { Candidates }\end{array}$ & $\begin{array}{c}\text { Total } \\
\text { Positions }\end{array}$ \\
\hline 1989-90 & 5 & 5 & 15 & 12 & 15 & 9 & 3 & 0 & 35 & 26 \\
\hline 1990-91 & 3 & 9 & 23 & 6 & 20 & 12 & 2 & 2 & 46 & 27 \\
\hline 1991-92 & 7 & 12 & 20 & 3 & 13 & 3 & 1 & 2 & 40 & 18 \\
\hline 1992-93 & 6 & 16 & 23 & 3 & 27 & 9 & 2 & 3 & 56 & 28 \\
\hline 1993-94 & 10 & 18 & 32 & 6 & 25 & 3 & 3 & 1 & 67 & 27 \\
\hline 1994-95 & 15 & 20 & 45 & 4 & 29 & 6 & 3 & 5 & 89 & 30 \\
\hline 1995-96 & 24 & 20 & 50 & 9 & 35 & 9 & 9 & 7 & 109 & 38 \\
\hline 1996-97 & 19 & 36 & 35 & 18 & 31 & 6 & 4 & 12 & 85 & 60 \\
\hline 1997-98 & 20 & 50 & 25 & 26 & 23 & 16 & 6 & 13 & 68 & 92 \\
\hline 1998-99 & 16 & 58 & 10 & 45 & 28 & 46 & 9 & 22 & 54 & 149 \\
\hline 1999-2000 & 17 & 92 & 17 & 67 & 27 & 69 & 10 & 21 & 61 & 228 \\
\hline 2000-01 & 15 & 82 & 25 & 56 & 27 & 59 & 5 & 26 & 67 & 197 \\
\hline 2001-02 & 24 & 54 & 28 & 65 & 24 & 56 & 12 & 16 & 74 & 175 \\
\hline 2002-03 & 31 & 83 & 19 & 50 & 29 & 57 & 6 & 19 & 79 & 190 \\
\hline 2003-04 & 35 & 74 & 33 & 67 & 30 & 44 & 22 & 20 & 98 & 185 \\
\hline 2004-05 & 33 & 94 & 40 & 65 & 33 & 53 & 15 & 17 & 106 & 212 \\
\hline 2005-06 & 33 & 141 & 59 & 104 & 49 & 82 & 25 & 36 & 141 & 316 \\
\hline 2006-07 & 62 & 111 & 63 & 82 & 57 & 64 & 44 & 34 & 184 & 263 \\
\hline 2007-08 & 90 & 165 & 87 & 90 & 54 & 111 & 62 & 76 & 231 & 366 \\
\hline 2008-09 & 57 & 128 & 106 & 63 & 107 & 74 & 61 & 66 & 270 & 265 \\
\hline 2009-10 & 42 & 153 & 48 & 68 & 91 & 85 & 48 & 75 & 181 & 306 \\
\hline 2010-11 & 45 & 149 & 47 & 41 & 121 & 93 & 58 & 60 & 213 & 283 \\
\hline 2011-12 & 51 & 202 & 54 & 66 & 139 & 51 & 82 & 104 & 245 & 319 \\
\hline 2012-13 & 82 & 302 & 87 & 78 & 50 & 61 & 65 & 118 & 219 & 441 \\
\hline 2013-14 & 63 & 168 & 49 & 53 & 35 & 37 & 44 & 81 & 147 & 258 \\
\hline 2014-15 & 67 & 329 & 57 & 84 & 39 & 58 & 45 & 132 & 163 & 471 \\
\hline
\end{tabular}

The lowest number of candidates (35) during the study occurred in the first year (1989/90). By 2014/15, the number of candidates was 163 , an increase of 366 or 14 percent a year.

In 2014/15, there were 2.9 jobs per candidate. In general, this is a very strong number for the field.
However, this number includes adjunct, visiting, and instructor positions along with tenure track jobs.

International. An interesting finding in the study is the explosive growth in the number of international jobs. In 2014/15, international positions peaked at 132 or $12 \%$ higher than the previous peak in 2012/13. During 2014/15 
Table 3. Rank of Tenure Track Candidates and Positions, 1989-June 2015

CANDIDATES

POSITIONS

\begin{tabular}{|c|c|c|c|c|c|c|c|c|c|c|c|c|c|c|}
\hline $\begin{array}{c}\text { Academic } \\
\text { Year }\end{array}$ & Assistant & Associate & Full & Endowed & Open & Total & $\%$ & Assistant & Associate & Full & Endowed & Open & Total & $\%$ \\
\hline 1989/90 & 24 & 4 & 2 & 0 & 5 & 35 & 100 & 19 & 0 & 0 & 3 & 4 & 26 & 100 \\
\hline 1990/91 & 34 & 4 & 1 & 0 & 3 & 42 & 91 & 19 & 0 & 0 & 3 & 3 & 25 & 93 \\
\hline 1991/92 & 29 & 5 & 1 & 0 & 5 & 40 & 100 & 10 & 1 & 0 & 3 & 1 & 15 & 83 \\
\hline 1992/93 & 29 & 4 & 2 & 0 & 7 & 42 & 75 & 15 & 0 & 0 & 4 & 4 & 23 & 82 \\
\hline 1993/94 & 30 & 4 & 1 & 0 & 5 & 40 & 60 & 18 & 0 & 1 & 3 & 1 & 23 & 85 \\
\hline 1994/95 & 46 & 2 & 0 & 0 & 5 & 53 & 60 & 14 & 2 & 0 & 2 & 5 & 23 & 77 \\
\hline 1995/96 & 51 & 1 & 0 & 0 & 3 & 55 & 50 & 22 & 2 & 1 & 5 & 4 & 34 & 89 \\
\hline 1996/97 & 48 & 1 & 0 & 0 & 5 & 49 & 58 & 23 & 6 & 0 & 8 & 14 & 51 & 85 \\
\hline 1997/98 & 63 & 0 & 0 & 0 & 4 & 67 & 99 & 41 & 4 & 3 & 5 & 7 & 60 & 65 \\
\hline 1998/99 & 37 & 3 & 0 & 0 & 9 & 49 & 91 & 58 & 17 & 5 & 10 & 51 & 141 & 95 \\
\hline 1999/00 & 47 & 1 & 1 & 1 & 5 & 58 & 95 & 88 & 21 & 3 & 23 & 81 & 216 & 95 \\
\hline 2000/01 & 49 & 1 & 0 & 0 & 12 & 62 & 84 & 52 & 16 & 4 & 18 & 97 & 187 & 95 \\
\hline $2001 / 02$ & 60 & 4 & 1 & 0 & 9 & 74 & 100 & 81 & 34 & 4 & 3 & 38 & 160 & 91 \\
\hline 2002/03 & 56 & 12 & 4 & 0 & 5 & 77 & 97 & 81 & 33 & 14 & 12 & 41 & 181 & 95 \\
\hline $2003 / 04$ & 66 & 11 & 6 & 2 & 11 & 96 & 98 & 63 & 40 & 8 & 13 & 47 & 171 & 92 \\
\hline 2004/05 & 75 & 8 & 4 & 0 & 15 & 102 & 96 & 64 & 59 & 9 & 17 & 35 & 184 & 87 \\
\hline 2005/06 & 87 & 24 & 0 & 2 & 24 & 137 & 97 & 71 & 110 & 14 & 24 & 73 & 292 & 92 \\
\hline 2006-07 & 98 & 52 & 3 & 1 & 29 & 183 & 99 & 71 & 55 & 8 & 13 & 36 & 183 & 69 \\
\hline 2007-08 & 185 & 20 & 6 & 4 & 7 & 222 & 96 & 84 & 107 & 12 & 17 & 68 & 288 & 79 \\
\hline 2008-09 & 209 & 34 & 10 & 5 & 2 & 260 & 96 & 69 & 46 & 12 & 22 & 16 & 165 & 66 \\
\hline 2009-10 & 144 & 18 & 6 & 0 & 1 & 169 & 93 & 75 & 47 & 14 & 17 & 34 & 187 & 60 \\
\hline 2010-11 & 181 & 17 & 3 & 0 & 0 & 201 & 94 & 66 & 59 & 18 & 16 & 23 & 182 & 65 \\
\hline $2011-12$ & 195 & 19 & 9 & 2 & 6 & 231 & 94 & 54 & 67 & 23 & 20 & 39 & 203 & 64 \\
\hline 2012-13 & 198 & 9 & 2 & 0 & 1 & 210 & 96 & 119 & 46 & 27 & 23 & 30 & 245 & 56 \\
\hline 2013-14 & 122 & 11 & 3 & 0 & 2 & 138 & 94 & 72 & 29 & 10 & 16 & 23 & 150 & 58 \\
\hline 2014-15 & 141 & 9 & 7 & 1 & 3 & 161 & 99 & 135 & 50 & 23 & 23 & 30 & 261 & 56 \\
\hline
\end{tabular}

the number of international candidates was only 45 . This puts the ratio of the total number of international positions per international candidate during 2014/15 at 2.93 jobs per candidate. These are very similar numbers to the overall number of positions and candidates in the table.
The increase in the number of candidates and jobs for both U.S. and international schools shows how the field has become increasingly institutionalized within Schools of Business and Management since 1991. Entrepreneurship has become a very popular subject and schools have accepted the field. 
Table 4. Percentage of Applicants and Positions Cross-Listed by Field, 1989-June 2015

CANDIDATES

POSITIONS

\begin{tabular}{|c|c|c|c|c|c|c|c|c|c|c|}
\hline $\begin{array}{l}\text { Academic } \\
\text { Year }\end{array}$ & $\begin{array}{l}\text { Entrepreneurship } \\
\text { Only }\end{array}$ & Strategy & International & $\mathrm{OB} / \mathrm{HR}$ & TIM & $\begin{array}{l}\text { Entrepreneurship } \\
\text { Only }\end{array}$ & Strategy & International & $\mathrm{OB} / \mathrm{HR}$ & TIM \\
\hline 1989/90 & $0 \%$ & $63 \%$ & $14 \%$ & $23 \%$ & $3 \%$ & $15 \%$ & $69 \%$ & $38 \%$ & $7 \%$ & $0 \%$ \\
\hline 1990/91 & $0 \%$ & $80 \%$ & $17 \%$ & $15 \%$ & $2 \%$ & $28 \%$ & $40 \%$ & $12 \%$ & $12 \%$ & $0 \%$ \\
\hline 1991/92 & $0 \%$ & $68 \%$ & $33 \%$ & $30 \%$ & $3 \%$ & $67 \%$ & $40 \%$ & $0 \%$ & $0 \%$ & $0 \%$ \\
\hline $1992 / 93$ & $0 \%$ & $73 \%$ & $25 \%$ & $21 \%$ & $13 \%$ & $65 \%$ & $30 \%$ & $26 \%$ & $13 \%$ & $0 \%$ \\
\hline $1993 / 94$ & $0 \%$ & $73 \%$ & $30 \%$ & $16 \%$ & $10 \%$ & $61 \%$ & $22 \%$ & $13 \%$ & $4 \%$ & $4 \%$ \\
\hline 1994/95 & $0 \%$ & $71 \%$ & $35 \%$ & $19 \%$ & $7 \%$ & $74 \%$ & $17 \%$ & $9 \%$ & $26 \%$ & $0 \%$ \\
\hline $1995 / 96$ & $3 \%$ & $65 \%$ & $32 \%$ & $28 \%$ & $8 \%$ & $35 \%$ & $21 \%$ & $15 \%$ & $18 \%$ & $3 \%$ \\
\hline 1996/97 & $1 \%$ & $73 \%$ & $33 \%$ & $26 \%$ & $6 \%$ & $37 \%$ & $41 \%$ & $22 \%$ & $33 \%$ & $8 \%$ \\
\hline $1997 / 98$ & $1 \%$ & $79 \%$ & $40 \%$ & $43 \%$ & $9 \%$ & $48 \%$ & $65 \%$ & $27 \%$ & $27 \%$ & $8 \%$ \\
\hline 1998/99 & $0 \%$ & $74 \%$ & $35 \%$ & $15 \%$ & $11 \%$ & $47 \%$ & $56 \%$ & $27 \%$ & $33 \%$ & $15 \%$ \\
\hline 1999/2000 & $1 \%$ & $60 \%$ & $30 \%$ & $21 \%$ & $16 \%$ & $24 \%$ & $37 \%$ & $15 \%$ & $18 \%$ & $14 \%$ \\
\hline 2000/01 & $0 \%$ & $76 \%$ & $33 \%$ & $19 \%$ & $25 \%$ & $26 \%$ & $38 \%$ & $18 \%$ & $19 \%$ & $16 \%$ \\
\hline $2001 / 02$ & $3 \%$ & $80 \%$ & $28 \%$ & $16 \%$ & $20 \%$ & $18 \%$ & $50 \%$ & $21 \%$ & $19 \%$ & $12 \%$ \\
\hline $2002 / 03$ & $0 \%$ & $72 \%$ & $33 \%$ & $25 \%$ & $15 \%$ & $25 \%$ & $48 \%$ & $16 \%$ & $17 \%$ & $9 \%$ \\
\hline $2003 / 04$ & $2 \%$ & $72 \%$ & $30 \%$ & $14 \%$ & $25 \%$ & $25 \%$ & $51 \%$ & $19 \%$ & $9 \%$ & $10 \%$ \\
\hline $2004 / 05$ & $0 \%$ & $68 \%$ & $32 \%$ & $16 \%$ & $17 \%$ & $22 \%$ & $51 \%$ & $18 \%$ & $15 \%$ & $11 \%$ \\
\hline $2005 / 06$ & $0 \%$ & $66 \%$ & $26 \%$ & $22 \%$ & $32 \%$ & $22 \%$ & $46 \%$ & $16 \%$ & $17 \%$ & $8 \%$ \\
\hline 2006/07 & $1 \%$ & $73 \%$ & $30 \%$ & $18 \%$ & $33 \%$ & $23 \%$ & $44 \%$ & $29 \%$ & $18 \%$ & $9 \%$ \\
\hline $2007 / 08$ & $2 \%$ & $71 \%$ & $31 \%$ & $21 \%$ & $23 \%$ & $22 \%$ & $45 \%$ & $18 \%$ & $22 \%$ & $14 \%$ \\
\hline 2008/09 & $2 \%$ & $70 \%$ & $30 \%$ & $17 \%$ & $25 \%$ & $20 \%$ & $46 \%$ & $20 \%$ & $20 \%$ & $16 \%$ \\
\hline 2009/10 & $5 \%$ & $89 \%$ & $49 \%$ & $41 \%$ & $48 \%$ & $33 \%$ & $37 \%$ & $19 \%$ & $21 \%$ & $17 \%$ \\
\hline 2010/11 & $3 \%$ & $77 \%$ & $45 \%$ & $41 \%$ & $40 \%$ & $46 \%$ & $30 \%$ & $15 \%$ & $13 \%$ & $9 \%$ \\
\hline $2011 / 12$ & $3 \%$ & $72 \%$ & $41 \%$ & $48 \%$ & $38 \%$ & $45 \%$ & $33 \%$ & $16 \%$ & $20 \%$ & $19 \%$ \\
\hline $2012 / 13$ & $5 \%$ & $64 \%$ & $22 \%$ & $22 \%$ & $24 \%$ & $52 \%$ & $30 \%$ & $14 \%$ & $9 \%$ & $7 \%$ \\
\hline 2013/14 & $5 \%$ & $62 \%$ & $20 \%$ & $24 \%$ & $23 \%$ & $51 \%$ & $25 \%$ & $10 \%$ & $10 \%$ & $5 \%$ \\
\hline $2014 / 15$ & $5 \%$ & $68 \%$ & $29 \%$ & $23 \%$ & $22 \%$ & $58 \%$ & $22 \%$ & $6 \%$ & $9 \%$ & $5 \%$ \\
\hline
\end{tabular}

Interest Level. Sixty-seven (41\%) of the total number of candidates in 2014/15 advertised entrepreneurship as their primary area of expertise. The number of candidates that listed entrepreneurship as their second area of expertise was 57 (35\%) and third area 39 (24\%). The number and percentage of job opportunities seeking people with entrepreneurship as their primary field of expertise in 2014/15 was 329 (70\%); secondary and tertiary numbers were 84 (18\%) and 58 (12\%), respectively.

Overall, in 2014/15, there were 4.9 primary jobs for each primary candidate. These numbers indicate a plethora of opportunities for candidates specializing

44 NEW ENGLAND JOURNAL OF ENTREPRENEURSHIP 
in entrepreneurship as their primary area of expertise. For whatever reason, candidates are not advertising entrepreneurship as their primary area of interest.

Perhaps the market feels the field is not legitimized and candidates believe they have to specialize in a more traditional area to earn a position. Entrepreneurship is still a relatively young field. For instance, strategic management is required in almost all curricula. By specializing in this area, candidates may be seeking a more secure route to a higher number of positions. Candidates may be hedging their risk by placing entrepreneurship second or even third. Candidates who are truly passionate about the field of entrepreneurship should list it as their primary interest when marketing themselves. The opportunities are there and it will signal to the market the candidate's strong intentions to become a scholar within the field.

Table 3 evaluates tenure track positions and candidates and their respective ranks. Once the numbers of tenure track positions were documented, they were cross-listed with the AACSB web site to determine the final number of AACSB positions.

In the most recent academic year there were 261 tenure track positions, the third largest number of tenure track positions since the study began. The number of tenure track positions increased by $74 \%$ from last year. However, it is smaller than the largest number of tenure track positions, 292, which occurred in 2005/06 right before the financial crisis.
In the most recent year, only $56 \%$ of the academic jobs were full-time tenure track positions. This is in tune with the drop in the overall percentage of tenure track positions. Only 174 (37\%) of all advertised jobs were tenure track positions at AACSB-accredited institutions.

In 2014/15, tenure track position advertisements by rank were 135 (52\%) assistant, 50 (19\%) associate, 23 (9\%) full, 23 (9\%) endowed chair, and 30 (11\%) open positions. More than 48 percent of the positions were seeking senior-level faculty. As the field continues to grow, many schools seek experienced veterans to build programs and enhance legitimacy. There are many job opportunities for senior-level faculty at other schools.

The number of candidates seeking tenure track positions in $2014 / 15$ was 161 . While this number is $17 \%$ higher than the previous year, the number of candidates has been decreasing since 2006/07. It could be that fewer people have decided to enter academia.

In 2014/15, the rank of advertised candidates was 141 (88\%) assistant, 9 (6\%) associate, 7 (4\%) full, 1 (.6\%) endowed chair, and 3 (2\%) open. In 2014/15, the ratio of tenure track positions (261) per tenure track candidates (161) was 1.62. The ratio of tenure track positions at AACSB schools per candidate was 1.08. Of course, this does not include some faculty who choose not to advertise themselves but are seeking opportunities discreetly. Thus, we can assume that there are more faculty seeking AACSB tenure track positions

Table 5. Average Entrepreneurship Faculty Salaries at AACSB Schools 2004-2015 (9-month salary)

\begin{tabular}{cccccc}
\hline Academic Year & Full Professor & Associate Professor & Assistant Professor & Instructor & New Doctorate \\
\hline $2004-2005$ & $\$ 115,500$ & $\$ 94,900$ & $\$ 87,100$ & $\$ 58,200$ & $\$ 85,800$ \\
$2005-2006$ & $\$ 123,900$ & $\$ 96,200$ & $\$ 90,900$ & $\$ 70,100$ & $\$ 92,500$ \\
$2006-2007$ & $\$ 131,400$ & $\$ 101,800$ & $\$ 94,800$ & $\$ 73,500$ & $\$ 96,900$ \\
$2007-2008$ & $\$ 140,200$ & $\$ 104,500$ & $\$ 97,800$ & $\$ 80,000$ & $\$ 104,300$ \\
$2008-2009$ & $\$ 148,100$ & $\$ 110,200$ & $\$ 100,600$ & $\$ 78,500$ & $\$ 99,900$ \\
$2009-2010$ & $\$ 154,600$ & $\$ 111,600$ & $\$ 103,100$ & $\$ 76,400$ & $\$ 123,300$ \\
$2010-2011$ & $\$ 153,300$ & $\$ 113,700$ & $\$ 106,400$ & $\$ 78,900$ & $\$ 117,700$ \\
$2011-2012$ & $\$ 156,800$ & $\$ 119,300$ & $\$ 109,600$ & $\$ 81,500$ & $\$ 112,200$ \\
$2012-2013$ & $\$ 164,000$ & $\$ 123,900$ & $\$ 111,000$ & $\$ 79,400$ & $\$ 111,400$ \\
$2013-2014$ & $\$ 165,800$ & $\$ 125,000$ & $\$ 113,700$ & $\$ 79,400$ & $\$ 119,600$ \\
$2014-2015$ & $\$ 162,000$ & $\$ 131,400$ & $\$ 113,600$ & $\$ 85,800$ & $\$ 97,800$ \\
\hline
\end{tabular}

Source: The data are based on a controlled group of 325 U.S. schools that completed an AACSB Salary Survey in each of the benchmarking years. 
than are available. As a result, candidates need to be prepared to possibly postpone taking a position at a school that is not accredited by the AACSB.

Table 4 documents the different areas that both candidates and schools advertise in their profiles. For instance, if Ted Baker was advertising for an entrepreneurshiponly position, he would only place entrepreneurship on his profile. If Brown University was seeking a primary candidate in entrepreneurship with secondary and tertiary areas in international management and technology and innovation management, it would list these in its profile.

This area is important to the field of entrepreneurship because it allows us to examine the trends that are occurring in the marketplace. If candidates can see the needs of the marketplace, they can be more proactive in their pursuit of specializations.

The table is broken down into five categories: entrepreneurship only, strategy, international, Organizational Behavior/Human Resources Management (OB/HR), and Technology and Innovation Management (TIM). The respective areas each have a percentage. The percentages for the positions in 2014/15 were entrepreneurship only (58\%), strategy (22\%), international management (6\%), OB/HR (9\%), and TIM (5\%). The percentages for candidates in 2014/15 were entrepreneurship only (5\%), strategy (68\%), international management (29\%), OB/HR (23\%), and TIM (22\%).

In addition to the five areas noted above, the following were also advertised by schools: management, marketing, organizational theory, business ethics/business society, operations, finance, research methods, management history, and organizational development. The percentage of jobs advertised in these areas was management (10\%), marketing (6\%), organizational theory (2\%), business ethics/business society (1\%), operations (1\%), and finance (1\%). The percentage of candidates that advertised in some of these areas was organizational theory (25\%), business ethics/business society (8\%), research methods (4\%), organizational development (2\%), management history (2\%), and operations (1\%).

Table 5 examines the average salaries of entrepreneurship faculty at AACSB schools in the United States from 2004-2015. In 2014/15, the average salaries for entrepreneurship faculty at AACSB schools were: full professor $(\$ 162,000)$, associate professor $(\$ 131,400)$, assistant professor $(\$ 113,600)$, instructor $(\$ 85,800)$, and new doctorates $(\$ 97,800)$.
Salaries went down for professors (2.3\%), assistant professors (.1\%) and new doctorates (18.2\%) since 2013-2014. Associate professor and instructor salaries both went up by $\$ 6,400$ or 5.1 percent and 8.1 percent, respectively. During 2014-2015, the difference in salary between an assistant professor and an associate professor was $\$ 17,800$ (15.7\%). The average difference in salary between an associate professor and a full professor was $\$ 30,600$ (23.3\%). From 2004-2005 to 2014-2015, the salary trends for each rank shows the following increases: full professor (\$46,500: 40\%), associate professor $(\$ 36,500$ : $38 \%)$, assistant professor ( $\$ 26,500: 30 \%)$, instructor (\$27,600: 47\%), and new doctorates (\$12,000: 14\%).

Table 6 shows the average salaries at AACSB institutions in the United States for 27 different areas during 2014/15. In comparing entrepreneurship faculty salaries to some of the major areas in business, we see that salaries are strong. At the full professor level, the average salary for entrepreneurship was $\$ 162,000$ compared to accounting $(\$ 162,200)$, finance $(\$ 189,000)$, management $(\$ 145,800)$, and marketing $(\$ 166,500)$.

At the associate professor level, the average salary for entrepreneurship was $\$ 131,400$ compared to accounting $(\$ 138,900)$, finance $(\$ 147,500)$, management $(\$ 117,700)$, and marketing $(\$ 127,500)$.

At the assistant professor level, the average salary for entrepreneurship was $\$ 113,600$ compared to accounting $(\$ 144,900)$, finance $(\$ 154,000)$, management $(\$ 109,100)$, and marketing $(\$ 123,400)$.

\section{Conclusion}

The purpose of this study was to investigate whether the field of entrepreneurship has become increasingly institutionalized within three areas: market trends, AACSB jobs, and salaries. To accomplish this, three research questions were formulated: (1) What are the market trends for entrepreneurship faculty? (2) What are the market trends for faculty in higher education for tenure track positions in entrepreneurship (including tenure track AACSB positions)? and (3) Are the average salaries of entrepreneurship faculty at AACSB schools in the United States competitive with other more established fields such as finance, accounting, management, and marketing?

The first research question asked: What are the market trends for entrepreneurship faculty? Table 2 shows that the field is becoming increasingly institutionalized. In 2014/15, the field saw the highest number of jobs advertisements

46 NEW ENGLAND JOURNAL OF ENTREPRENEURSHIP 
Table 6. Average Faculty Salary by Discipline and Rank in 2014-2015 (000s) (9-month salary)

\begin{tabular}{|c|c|c|c|c|}
\hline Discipline & Professor & Associate Professor & Assistant Professor & Instructor \\
\hline Accounting & 162.2 & 138.9 & 144.9 & 78.9 \\
\hline Behavioral Science/ Org Behavior & 193.5 & 140.0 & 135.6 & 86.9 \\
\hline Bus Education & 133.3 & 78.9 & 75.0 & 83.1 \\
\hline Bus Law/ Legal Environment & 131.3 & 103.2 & 91.5 & 72.7 \\
\hline CIS/ MIS & 149.3 & 121.5 & 112.6 & 73.8 \\
\hline Econ/Managerial Economics & 141.6 & 104.3 & 101.2 & 67.7 \\
\hline Finance (incl Banking) & 189.0 & 147.5 & 154.0 & 90.2 \\
\hline Health Services/ Hospital Admin & 174.4 & 124.9 & 111.2 & 79.6 \\
\hline Hotel/ Restaurant/Tourism & 119.6 & 96.0 & 87.7 & 69.9 \\
\hline Insurance & 167.7 & 136.3 & 125.1 & 80.3 \\
\hline International Bus & 152.1 & 125.4 & 117.8 & 82.8 \\
\hline Management & 145.8 & 117.7 & 109.1 & 75.6 \\
\hline Marketing & 166.5 & 127.5 & 123.4 & 75.5 \\
\hline Operations Research & 181.0 & 127.6 & 135.3 & 84.2 \\
\hline Production/ Operations Mgt & 159.7 & 134.0 & 126.8 & 84.4 \\
\hline Strategic Management & 182.4 & 136.7 & 129.3 & 91.5 \\
\hline Public Administration & 170.1 & 104.6 & 128.6 & 72.9 \\
\hline Quantitative Methods & 146.7 & 114.3 & 110.6 & 69.1 \\
\hline Real Estate & 181.5 & 143.8 & 145.5 & 83.9 \\
\hline Statistics & 152.8 & 112.6 & 111.8 & 68.2 \\
\hline Taxation & 141.1 & 120.4 & 127.5 & 84.2 \\
\hline Supply Chain/Transport/ Logistics & 158.3 & 135.6 & 120.3 & 86.2 \\
\hline Other & 181.6 & 108.3 & 110.9 & 79.5 \\
\hline Bus Communication & 110.8 & 92.6 & 77.3 & 62.9 \\
\hline Bus Ethics (incl Corp Soc Resp) & 159.8 & 119.2 & 115.2 & 89.9 \\
\hline Entrepreneurship/ Small Bus Admin & 162.0 & 131.4 & 113.6 & 85.8 \\
\hline HR Mgt (incl Persnl and Ind/Labor Rel) & 136.8 & 120.3 & 107.6 & 66.8 \\
\hline E-Bus (incl E-commerce) & 148.1 & 98.1 & 110.6 & 53.5 \\
\hline General Bus & 124.6 & 66.0 & 78.0 & 68.7 \\
\hline
\end{tabular}

Source: $A A C S B$ 
(471) since the inception of the study in 1989. The ratio of total jobs per candidate was 2.9, which was the second highest since 1989. This is a very strong number and proof that the field of entrepreneurship is increasingly becoming part of the curriculum within Schools of Business and Management.

Another sign of the field becoming increasingly institutionalized is the growth of international positions. There were 132 international positions in 2014/15, the second highest since 1989. The ratio of international positions per international candidate during 2014/15 was 2.93 .

A final sign of increasing institutionalization was the number of jobs advertising for a candidate with a primary specialization in entrepreneurship. Of the job advertisements, 329 (70\%) were for a candidate with a primary focus on entrepreneurship.

The second research question addressed in this study was: What are the trends in the market for faculty in higher education for tenure track positions in entrepreneurship (including tenure track AACSB positions)? In 2014/15, there were 261 tenure track positions. This was the third highest number of tenure track positions since 1989. The largest number of tenure track positions in the study peaked in 2005/06 at 292.

Of the 261 tenure track positions, 174 (67\%) were documented as tenure track positions at AACSB accredited institutions. This was a very strong number compared to the only other study that was done on this topic. Finkle's (2007a) study found that there were 122 tenure track AACSB positions in 2004/05, an increase of 49 (40\%). Thus, we can say that there is an increase in demand for tenure track AACSB faculty to fill these positions since 2004/05. This is a sign that more institutions are incorporating entrepreneurship into their curriculum.

The final research question the study examined was: Are the average salaries of entrepreneurship faculty at AACSB schools in the United States competitive with other more established fields such as finance, accounting, management, and marketing. The answer to this question is yes. As pointed out in Table 6, the salaries are competitive to other more established fields. Entrepreneurship even leads management at every rank. It also leads associate professors in marketing, and is comparable to full professors of accounting.

Does having a competitive salary at U.S. AACSB schools mean that entrepreneurship is institutionalized? Could it mean that there is a shortage of faculty in entrepreneurship and they have to increase salaries to be competitive within the marketplace? It could mean that there is a strong demand for tenure track faculty due to the 174 openings. These numbers reflect a demand for entrepreneurship education. By hiring tenure track faculty to teach these courses, the institutionalization of the field is enhanced.

In summary, the findings of this study support the notion that the field of entrepreneurship is institutionalized in regards to job opportunities, candidates, AACSB positions, and salaries.

\section{Implications for Faculty and Doctoral Students}

The findings of this study have several implications for faculty and doctoral students in the field of entrepreneurship. There is a plethora of opportunities to specialize in entrepreneurship. During 2014/15, the field saw the second highest number of tenure track positions advertised (261 versus 161 candidates seeking a tenure track position). There were 1.62 tenure track jobs per tenure track candidate. This is encouraging news for candidates. This data confirms that there is ample opportunity for faculty who are interested in pursuing entrepreneurship as their primary area of expertise. Therefore, it is recommended that candidates who are seriously interested in a career in entrepreneurship place this as their primary area of interest.

Candidates have the ability to create a competitive advantage in the marketplace by specializing in entrepreneurship. However, candidates must back up their abilities. Merely placing entrepreneurship as a primary area is fruitless if a candidate does not have the skill set. Candidates must seek out the specific needs for each position. Entrepreneurship is unlike other areas due to the strong practical dimensions of the field. The field may require a wide diversity of skill sets. Depending on the institution, some may require extremely strong research-oriented skills (research schools) and/or strong teaching skills (teaching schools). Significant differences and expectations can exist between institutions. These expectations need to be ferreted out before taking a job.

Most schools value scholarship differently. Schools usually have a list to classify journals (e.g., A, B, and $C$ ), but some schools may not even have one. As long as the study is refereed, that is what is required. It is imperative that faculty inquire about the rankings of entrepreneurship journals and where they should be publishing. In the early years, faculty had to fight for legitimacy due to the liability of newness (Stinchcombe, 1965) of the field. Although the field has come a long 
way, there is no guarantee that some faculty may question research in entrepreneurship.

Some schools may be seeking entrepreneurship faculty who can create and grow a new entrepreneurship center or build a new program. Thus, a different type of skill set may be necessary such as sales, branding, advertising, fund-raising, etc. In general, the field values faculty who have entrepreneurial experience plus academic credentials. However, there are not as many of these individuals within the ranks of academia.

As the field continues to grow, schools will need faculty to build programs. There will be opportunities for junior and senior faculty to apply for these openings. However, faculty must be aware of the enormous amount of time it takes to build a program. This could restrict research productivity. It is recommended that junior faculty talk with several senior faculty members from other schools that have built programs to assist them in their decision making. Each institution will have its own history and specific needs.

The findings of this study also show a very strong demand for senior-level faculty. In 2014/15, 48 percent of the positions were seeking senior-level faculty. Due to the newness of the field and the small number of doctoral programs specializing in entrepreneurship, senior faculty are in demand. If senior faculty feel that they are being underpaid by their current institution, they can use these numbers to negotiate better deals (e.g., move from assistant to associate or associate to full or full to endowed chair). The findings of this study also give candidates the ability to negotiate their current salary to current market rates. For instance, in 2014/15, the average salary of full professors of entrepreneurship was $\$ 162,000$ at AACSB schools in the United States. If an associate professor with a strong record is being underpaid, he or she should seriously consider moving to another school as a full professor.

For international candidates, the findings of the study are extremely positive. In 2014/15, there were 132 positions and only 45 candidates or 2.93 international jobs per international candidate. These statistics are very similar to the overall number of positions and candidates in the table.

\section{Implications to Administrators}

The findings of this study show the challenges that administrators face in trying to start and/or build an entrepreneurship program. As noted above, in 2014/15, the field saw the second highest number of tenure track positions advertised at 261 versus 161 candidates seeking a tenure track position (1.62 tenure track jobs per tenure track candidate). Administrators may have a hard time filling a slot with a qualified applicant. And if they do find someone, they may have to pay a higher rate to hire them. Also noteworthy is that 96 senior-level tenure track jobs were advertised in 2014/15 by schools. Thirty-seven percent of all tenure track jobs were for senior-level faculty (associate or above).

The findings in this study show that 2014/15 entrepreneurship salaries at AACSB institutions in the United States were relatively strong. The average ninemonth salary for full professors in entrepreneurship was $\$ 162,000$ compared to accounting $(\$ 162,200)$, Finance $(\$ 189,000)$, management $(\$ 145,800)$, and marketing $(\$ 166,500)$. The average nine-month salary for associate professors in entrepreneurship was $\$ 131,400$ compared to accounting $(\$ 138,900)$, finance $(\$ 147,500)$, management $(\$ 117,700)$, and marketing $(\$ 127,500)$. It is evident that senior faculty in entrepreneurship are being valued competitively compared to other fields in business.

When recruiting candidates, administrators should have a clear vision on the role entrepreneurship will play in the future of the college and the university. Administrators need to communicate how the candidate fits into that vision. Also, administrators should communicate to candidates what their expectations are in research, teaching, and service.

\section{Limitations}

This study has a few limitations. Advertising for a position does not mean that a school will actually hire a candidate. The school may have the position pulled due to budgetary issues. The school may decide not to hire anyone because they cannot find the right match. Another limitation is the inability to capture all of the job advertisements. Although, data is collected almost every day, there may be some cites that the author is not aware of that may have data that would enhance the study. Finally, the study was not able to capture the names and descriptions of faculty who already have positions and decided not to list themselves on any site. 


\section{Future Research}

Future research can be done to examine the institutionalization of the field of entrepreneurship by comparing the trends in salaries between fields over the long run. Are entrepreneurship faculties being paid at a competitive rate versus other mainstream fields that have achieved institutionalization within Schools of Business and Management? Are faculties that are being hired as full-time entrepreneurship faculty members getting tenure? And if so, what requirements or demands are being placed on them at different types of institutions (e.g., teaching versus research schools)? How are schools valuing entrepreneurship journals? Are entrepreneurship faculties moving up in schools to management levels (e.g., deans, chairs of departments, etc.)? These are a few of the areas that can be investigated in future research.

\section{REFERENCES}

AACSB International. 2015. The Association to Advance Collegiate Schools of Business. Retrieved June 30, 2015, from: http://www.aacsb.edu/accreditation/

AACSB International. Average Annual Salary Survey of AACSB Business Faculty 2000-2015. Tampa, FL.

Academy of Management Placement Roster. Academy of Management Placement Service. Used all volumes from 1989-2015.

Bruton, G., D. Ahlstrom, and H. Li (2010). Institutional Theory and Entrepreneurship: Where Are We Now and Where Do We Need to Be in the Future? Entrepreneurship Theory \& Practice. May, 421-440.

Chronicle of Higher Education. Washington, D.C. All volumes from 1989-2015.

Dowling, J., and J. Pfeffer. 1975. Organizational Legitimacy: Social Values and Organizational Behavior. Pacific Sociological Review 18, 122-136.

Finkle, T. A. 2016. A Current Look at Salaries and Faculty Demand within the Field of Entrepreneurship. Journal of Applied Management \& Entrepreneurship 21 (2): 45-69.

Finkle, T. A. 2013a. Job Opportunities for Faculty in the Field of Entrepreneurship. Journal of Applied Management and Entrepreneurship 18 (3): 94-112.

Finkle, T. A. 2013b. Trends in the Market for Entrepreneurship Faculty from 1989-2011. Journal of Entrepreneurship Education 16, Special Issue, 59-76.

Finkle, T. A. 2012a. Trends in the Market for Entrepreneurship Faculty during the Period 1989 to 2010. Journal of Entrepreneurship Education 15, 21-40.

Finkle, T. A. 2012b. Trends in the Field of Entrepreneurship from 1989-2011. 26th Proceedings of the Annual National United States Association for Small Business and Entrepreneurship Conference, 1042-1055.

Finkle, T. A. 2010. Entrepreneurship Education Trends. Research in Business and Economics Journal February, 1, 35-53.

Finkle, T. A. 2008. Global Trends in the Job Market for Faculty and Schools in the Field of Entrepreneurship. Proceedings of the 2008 Annual American Society of Business and Behavioral Sciences National Conference (ASBSS), 803-810.

Finkle, T. A. 2007a. Trends in the Market for Entrepreneurship Faculty from 1989-2005. Journal of Entrepreneurship Education, 10, 1-25.

50 NEW ENGLAND JOURNAL OF ENTREPRENEURSHIP 
Finkle, T. A. 2007b. A Comparative Analysis of U.S. versus International Entrepreneurship Centers. $21^{\text {st }}$ Proceedings of the Annual National United States Association for Small Business and Entrepreneurship Conference, 125.

Finkle, T. and D. Deeds. 2002. Trends in the Market for Entrepreneurship Faculty from 1989-2001. 16 th $^{\text {Proceedings of the }}$ Annual National United States Association for Small Business and Entrepreneurship Conference, 121.

Finkle, T. A. and D. Deeds. 2001. Trends in the Market for Entrepreneurship Faculty during the Period 1989-1998. Journal of Business Venturing 16 (6): 613-630.

Finkle, T. A. and D.F. Kuratko. 2006. An Examination of Entrepreneurship Centers in the United States: A National Survey. Proceedings of the 2005 International Conference for Small Business.

Finkle, T. A. and D. F. Kuratko. 2004. Characteristics of the Top Ranked Entrepreneurship Centers. Frontiers of Entrepreneurship Research 2003: Proceedings of the Twenty-Third Annual Frontiers of Entrepreneurship Research Conference, Edited by William D. Bygrave, Candida Brush, Per Davidson, Patricia Greene, R. Harrison, James O. Feit, Miri Lerner, G. Dale Meyer, Jeffrey Sohl, and A. Zacharackis. Babson College: MA.

Finkle, T. A., D. F. Kuratko, and M. Goldsby. 2006a. An Examination of Entrepreneurship Centers in the United States: A National Survey." 50th Anniversary Special Issue of the Journal of Small Business Management 44 (2): 184-206.

Finkle, T. A., D. F. Kuratko and M. Goldsby. 2006b. The State of Entrepreneurship Centers in the United States: A Nationwide Survey. Proceedings of the 2005International Conference for Small Business (ICSB).

Finkle, T.A., T. V. Menzies, D. F. Kuratko and M. Goldsby. 2013. An Examination of the Financial Challenges of Entrepreneurship Centers Throughout the World. Journal of Small Business and Entrepreneurship 26 (1): 67-85.

Finkle, T.A., T. V. Menzies, D. F. Kuratko and M. Goldsby. 2012. Financing Activities of Entrepreneurship Centers in the United States. Journal of Business And Entrepreneurship 23 (2): 48-64.

Finkle, T.A., T. V. Menzies, M. Goldsby and D. F. Kuratko. 2010. A Global Examination of the Financial Challenges of Entrepreneurship Centers. Proceedings of the 2010 International Conference for Small Business (ICSB), 1-39.

Finkle, T. A., P. Stetz and D. Deeds. 2004. An Examination of Tenure Decisions for the Field of Entrepreneurship. Frontiers of Entrepreneurship Research 2003: Proceedings of the Twenty-Third Annual Frontiers of Entrepreneurship Research Conference, Edited by William D. Bygrave, Candida Brush, Per Davidson, Patricia Greene, R. Harrison, James O. Feit, Miri Lerner, G. Dale Meyer, Jeffrey Sohl, and A. Zacharakis. Babson College: MA. http://www.babson.edu/entrep/fer/BABSON2003/IX/IX-S3/IX-S3.html

Finkle, T.A., P. Stetz and M. Mallin. 2007. Perceptions of Tenure Requirements and Research Records of Entrepreneurship Faculty Earning Tenure: 1964-2002. Journal of Entrepreneurship Education 10, 101-125.

Katz, J.A. (2004). Survey of Endowed Positions in Entrepreneurship and Related Fields in the United States. Kansas City, MO: Kauffman Foundation.

Loundsbury, M. 2002. Institutional Transformation and Status Mobility: The Professionalization of the Field of Finance. Academy of Management Journal, 45 (1): 255-266.

Meyer, J. W. and B. Rowan. 1977. Institutionalized Organizations: Formal Structure as Myth and Ceremony. American Journal of Sociology 83 (2): 340-363.

Stinchcombe, A.L. 1965. Social structure and organizations in March, J. (Ed.), Handbook of Organizations.

Chicago: Rand McNally, pp. 142-193. 


\section{ABOUT THE AUTHOR}

Todd A. Finkle (finklet2000@yahoo.com) is the Pigott Professor of Entrepreneurship at Gonzaga University. He is an entrepreneur, author, consultant, and speaker and has consulted with countries, companies, and universities from all over the world. He has been an entrepreneur of four companies and cofounded a nonprofit. He has taught for 27 years and published 220 books, articles, presentations, and grants on entrepreneurship. One of his articles led to the creation of a relationship with Warren Buffett, who personally invited Dr. Finkle twice to visit him. He has brought six different groups of students to visit Buffett. Dr. Finkle won a national teaching award through U.S. Association for Small Business and Entrepreneurship and was runner-up for the most innovative entrepreneurship educator in the world by the AOM and is a MOOT CORP® Fellow through the $\mathrm{IC}^{2}$ Institute at the University of Texas at Austin. 